\title{
Isolation and molecular identification of Vibrio spp. by sequencing of $16 S$ rDNA from seafood, meat and meat products in Libya
}

\author{
S.M. Azwai ${ }^{1}$, E.A. Alfallani ${ }^{1}$, S.K. Abolghait ${ }^{2}$, A.M. Garbaj ${ }^{3}$, H.T. Naas ${ }^{3}$, A.A. Moawad ${ }^{4}$, F.T. Gammoudi ${ }^{1}$, \\ H.M. Rayes ${ }^{1}$, I. Barbieri ${ }^{5}$ and I.M. Eldaghayes ${ }^{1, *}$ \\ ${ }^{1}$ Department of Microbiology and Parasitology, Faculty of Veterinary Medicine, University of Tripoli, \\ P.O. Box 13662, Tripoli, Libya \\ ${ }^{2}$ Department of Food Hygiene and Control, Faculty of Veterinary Medicine, Suez Canal University, 41522 Ismailia, Egypt \\ ${ }^{3}$ Department of Food Hygiene and Control, Faculty of Veterinary Medicine, University of Tripoli, \\ P.O. Box 13662, Tripoli, Libya \\ ${ }^{4}$ Department of Food Hygiene and Control, Faculty of Veterinary Medicine, Cairo University, 12211 Giza, Egypt \\ ${ }^{5}$ Istituto Zooprofilattico Sperimentale della Lombardia e dell'Emilia Romagna, Via Bianchi, 9 - 25124 Brescia, Italy
}

\begin{abstract}
The genus Vibrio includes several food-borne pathogens that cause a spectrum of clinical conditions including septicemia, cholera and milder forms of gastroenteritis. Several Vibrio spp. are commonly associated with food-borne transmission including Vibrio cholerae, Vibrio parahemolyticus, and Vibrio vulnificus. Microbiological analysis for enumeration and isolation of Vibrio spp. were carried out for a total of 93 samples of seafood, meat and meat products from different geographic localities in Libya (Tripoli, Regdalin, Janzour and Tobruk). Vibrio spp. were detected by conventional cultural and molecular method using PCR and sequencing of 16S rDNA. Out of the 93 cultured samples only 48 (51.6\%) yielded colonies on Thiosulfate Citrate Bile Salt agar (TCBS) with culture characteristics of Vibrio spp. More than half $(n=27)$ of processed seafood samples $(n=46)$ yielded colonies on TCBS, while only $44.6 \%$ of samples of meat and meat products showed colonies on TCBS. Among cultured seafood samples, the highest bacterial count was recorded in clam with a count of $3.8 \times 10^{4} \mathrm{CFU} \backslash \mathrm{g}$. Chicken burger samples showed the highest bacterial count with $6.5 \times 10^{4} \mathrm{CFU} \backslash \mathrm{g}$. Molecular analysis of the isolates obtained in this study, showed that 11 samples out of $48(22.9 \%)$ were Vibrio spp. Vibrio parahemolyticus was isolated from camel meat for the first time. This study is an initial step to provide a baseline for future molecular research targeting Vibrio spp. foodborne illnesses. This data will be used to provide information on the magnitude of such pathogens in Libyan seafood, meat and meat products. Keywords: $16 \mathrm{~S}$ rDNA, Libya, Meat, Seafood, Vibrio.
\end{abstract}

\section{Introduction}

Libya enjoys one of the longest coastlines $(1800 \mathrm{~km})$ on the southern Mediterranean basin; this makes seafood an important item for consumers. In general, the overall consumption of meat and meat products in Libya is increasing with the consumption of camel meat being higher than beef. This increase in meat consumption is including as well various traditional meat products that have long been known in the country and prepared by families at home or during religious feasts.

Improperly handled seafood, meat and meat products could pose a great source of infectious agents that are transmissible to humans. Vibrio spp. are among the infectious agents that can result in deterioration of meat or represent a potential disease source for humans. The risk of disease from ingesting pathogens found in raw meat is significantly higher than cooked meat, although both can be contaminated (Newell et al., 2010). Meat can be incorrectly or insufficiently cooked, allowing disease-carrying pathogens to be ingested. In addition, meat can be contaminated during the production process at any time, from the slicing of prepared meats to cross-contamination of food in a refrigerator. All of these situations may lead to a greater risk of disease. From public health point of view, Vibrio spp. represents a greater portion of the food borne illnesses across the coast cities worldwide (Rebaudet et al., 2013). This could be due to food contamination with Vibrio spp. shed from seafood or prevalent usage of undercooked seafood/meat or surface contamination during marine shipping of such foods. Despite the vast majority of environmental $V$. parahemolyticus isolates are avirulent, it is leading cause of gastroenteritis linked to seafood consumption in the United States (Iwamoto et al., 2010). Some Vibrio spp. poses a significant health threat to humans who suffer from immune disorders and liver diseases. It enters human hosts via wound infections or consumption of raw shellfish (primarily oysters), and infections frequently progresses to septicemia and death in susceptible individuals (Harwood et al., 2004). The cosmopolitan distribution of Vibrio spp. and the lack of abattoirs for proper meat inspection, prompted us 
to carry out this study. The main objective of this study was to characterize bacteria isolated from seafood, meat and meat products that may cause foodborne illnesses. We plan to use this data to help create a baseline for future research into foodborne illness in Libya.

\section{Collection of samples}

\section{Materials and Methods}

A total of 93 samples (Table 1) of seafood, meat and meat products that includes 21 of shrimps; 5 of clam; 20 of fish; 34 samples of raw meat (10 beef, 9 camel meat, 6 mutton and 9 chickens) and 13 samples of meat products ( 2 beef sausages, 5 beef burgers, 5 chicken burgers and 1 kebab) were randomly collected from different geographic localities in Libya [Tripoli, Regdalin (120 km west of Tripoli), Janzour (30 km west of Tripoli) and Tobruk (1400 km east of Tripoli)]. Each sample was $250 \mathrm{~g}$ in weight. The Samples were packed in sterile plastic bags and stored in an insulated box containing crushed ice. The samples were transferred as quickly as possible to Food Hygiene and Control Laboratory at the Faculty of Veterinary Medicine, University of Tripoli. All samples were subjected to Vibrio spp. microbiological enumeration and isolation. Samples processing

Preparation of samples, decimal dilutions, culturing and enumeration techniques of bacteria were performed according to the methods described previously (Downes and Ito, 2001). Briefly, $25 \mathrm{~g}$ from each sample was aseptically transferred into a sterile polyethylene stomacher bag and blended with $225 \mathrm{ml}$ of sterile alkaline peptone water (Catalogue \#610098, LIOFILCHEM, Italy) in a stomacher homogenizer (Stomacher 400, Seaward medicals, UK.) at $230 \mathrm{rpm}$ for $60 \mathrm{~s}$. Serial dilutions were made using sterile $0.1 \%$ peptone water.

\section{Isolation, cultural characteristics and enumeration} of Vibrio spp.

Determination of the Vibrio spp. count was performed using Vibrio spp. selective Thiosulfate Citrate Bile Salt agar plates (TCBS: catalogue \#611010, LIOFILCHEM, Italy). TCBS agar plates were inoculated by spreading $0.1 \mathrm{ml}$ of the serial dilutions and incubated at $37^{\circ} \mathrm{C}$ for $48 \mathrm{~h}$. TCBS plates were examined for the presence of either yellow, round, 2-3 $\mathrm{mm}$ diameter colonies (suspect: V. cholera, $V$. fluvialis or $V$. alginolyticus) or green, round, 2-3 mm diameter colonies (suspect: $V$. parahemolyticus or $V$. vulnificus). Countable plates are those containing 25 to 250 colonies (Kaysner and DePaola, 2001).

\section{Purification of Vibrio spp.}

For purification, single colony from each grown type of Vibrio suspect colonies was streaked onto another TCBS agar and incubated overnight at $37^{\circ} \mathrm{C}$. This process has been performed until obtaining pure consistent colonies.

Table 1. Total number, enumeration and molecular identification of suspected Vibrio spp. in processed samples.

\begin{tabular}{|c|c|c|c|c|}
\hline Type of sample & $\begin{array}{l}\text { No. of } \\
\text { samples }\end{array}$ & $\begin{array}{l}\text { No. of suspected Vibrio spp. } \\
\text { growth on TCBS (\%) }\end{array}$ & $\begin{array}{l}\text { No. of positive Vibrio spp. } \\
\text { by } 16 \mathrm{~S} \text { r DNA sequencing }\end{array}$ & $\begin{array}{c}\text { Average } \\
\mathrm{CFU} / \mathrm{g}\end{array}$ \\
\hline Shrimp & 21 & $11(52.3)$ & 1 & $6.25 \times 10^{2}$ \\
\hline Clam & 5 & $4(80)$ & 1 & $3.8 \times 10^{4}$ \\
\hline Sardine & 8 & $7(87.5)$ & 3 & $3.7 \times 10^{3}$ \\
\hline Mackerel & 4 & $3(75)$ & 3 & $3.8 \times 10^{3}$ \\
\hline Annular sea bream & 2 & $1(50)$ & 1 & $4.5 \times 10^{3}$ \\
\hline Amberjack & 1 & None & None & - \\
\hline Common dentex & 1 & $1(100)$ & 1 & $3.7 \times 10^{3}$ \\
\hline Shark & 1 & None & None & - \\
\hline Dusky grouper & 2 & None & None & - \\
\hline Sea needle & 1 & None & None & - \\
\hline Beef & 10 & $5(50)$ & None & $2.9 \times 10^{3}$ \\
\hline Camel meat & 9 & $3(33.33)$ & 1 & $5.3 \times 10^{2}$ \\
\hline Chicken & 9 & $5(55.55)$ & None & $7.2 \times 10^{3}$ \\
\hline Mutton & 6 & None & None & - \\
\hline Beef burger & 5 & $4(80)$ & None & $1.2 \times 10^{4}$ \\
\hline Chicken burger & 5 & $4(80)$ & None & $6.5 \times 10^{4}$ \\
\hline Beef kebab & 1 & None & None & - \\
\hline Beef sausage & 2 & None & None & - \\
\hline Total & 93 & $48(51.6)$ & 11 & \\
\hline
\end{tabular}




\section{Identification of Vibrio spp. by PCR and sequencing} of $16 S \mathrm{rDNA}$

\section{DNA extraction of Vibrio isolates}

The procedure of DNA extraction of Vibrio isolates was done using the GF-1 bacterial DNA extraction kit (Cat\# GF-BA-100, Vivantis, Malaysia). Briefly, a single colony of pure isolate was picked up from TCBS agar and inoculated into $5 \mathrm{ml}$ nutrient broth then incubated at $37^{\circ} \mathrm{C}$. A total volume of $1-3 \mathrm{ml}$ of bacterial culture was centrifuged at $10000 \mathrm{rpm}$ for 2 min then supernatant was discarded. The pellet was then re-suspended by adding $100 \mu \mathrm{l}$ of buffer R1 (Cat. \# GF-BA-100, Vivantis, Malaysia).

The re-suspended cells were centrifuged at $10000 \mathrm{rpm}$ for $5 \mathrm{~min}$ then the supernatant was decanted completely. The protein of the pellet was denaturized by re-suspension in $180 \mu 1$ of Buffer R2 (Cat. \# GF-BA-100, Vivantis, Malaysia) and $20 \mu 1$ of proteinase $\mathrm{K}$, then incubated at $65^{\circ} \mathrm{C}$ for 20 min with shaking every $5 \mathrm{~min}$. Homogenization was achieved by adding $400 \mu 1$ of Buffer BG (Cat. \# GF-BA100 , Vivantis, Malaysia) and mix by inverting tube and incubation at $65^{\circ} \mathrm{C}$ for $10 \mathrm{~min} .200 \mu \mathrm{l}$ of absolute ethanol was added with immediate mixing to prevent precipitation of DNA due to high ethanol concentration. The sample was transferred (maximum volume $650 \mu \mathrm{l}$ ) into the column and centrifuged at $10000 \mathrm{rpm}$ for $1 \mathrm{~min}$. The flow was discarded and the column was washed by $750 \mu \mathrm{l}$ of wash buffer (Cat. \# GF-BA-100, Vivantis, Malaysia) by centrifugation at $10000 \mathrm{rpm}$ for $1 \mathrm{~min}$. The flow was discarded the DNA was eluted in $50 \mu \mathrm{l}$ of elution buffer, which left for $5 \mathrm{~min}$ at room temperature and then centrifuged at $1500 \mathrm{rpm} 1 \mathrm{~min}$.

\section{Amplification of $16 \mathrm{~S}$ rDNA}

Partial 16S rDNA was amplified using the universal oligonucleotides primers Forward S-D-Bact-0341b-S-17 and Reverse S-D-Bact-0785-a-A-21 adopted from (Herlemann et al., 2011). Briefly, $0.2 \mu \mathrm{g}$ of genomic DNA was added to $25 \mu \mathrm{l}$ Maximo Dry PCR Master Mix (Cat. \# S295, GeneON, UK). The mixture was then amplified in a DNA Thermal Cycler (TECHNE TC-512) using the following program: one denaturation step at $94{ }^{\circ} \mathrm{C}$ for $5 \mathrm{~min} ; 35$ cycles of denaturation, $92{ }^{\circ} \mathrm{C}$ for $30 \mathrm{~s}$, annealing temperature for $30 \mathrm{~s}$ at $55^{\circ} \mathrm{C}$, extension at $68{ }^{\circ} \mathrm{C}$ for $60 \mathrm{~s}$; and a final extension at $72{ }^{\circ} \mathrm{C}$ for $10 \mathrm{~min}$.

The PCR products were electrophoresed in $2 \%$ agarose gel (Cat. \# 604-005, GeneON, UK) incorporated with nucleic acid gel stain - 10000X (Gel RED, Cat. \# S420, GeneON, UK) at voltage 100 volt for one hour (SCIE-PLAS, UK). The sizes of the amplified fragments were determined by comparison with the GelPilot $100 \mathrm{bp}$ increment Ladder (Qiagen, Cat. No. 239035, Melbourne Australia) a ready-to-use 6 fragments (100-600 bp) DNA marker. The gel was photographed with gel-documentation system micro DOC with UV-trans-illuminator (CSLUVTS312, Cleaver Scientific, UK).

\section{DNA sequencing and analysis}

The amplified 16S rDNA PCR fragment (464 bp) was excised from the gel and the DNA was extracted from the gel using GF-1 Ambi Clean kit (Cat. \# GF-GC100 , Vivantis, Malaysia). Briefly, the net weight of gel slice was determined and 1 volume of Buffer DB was added to 1 volume of gel (A gel slice of mass $0.1 \mathrm{~g}$ will have a volume of $100 \mu \mathrm{l}$ ). Then the gel was incubated at $50^{\circ} \mathrm{C}$ until gel has melted completely. The sample was transferred into a column assembled in a clean collection tube. Centrifuge at $10000 \mathrm{rpm}$ for $1 \mathrm{~min}$. The flow was discarded and the column was washed with $750 \mu \mathrm{l}$ buffer and centrifuged at $10000 \mathrm{rpm}$ for $1 \mathrm{~min}$. The flow was discarded $\mathrm{t}$ and the column was dried by centrifugation at $10000 \mathrm{rpm}$ for $1 \mathrm{~min}$ to remove residual ethanol. DNA was then eluted by adding $30 \mu \mathrm{l}$ of elution buffer and mixture was left for $2 \mathrm{~min}$.

The purified 16S rDNA amplicons underwent cycle sequencing by Big Dye ${ }^{\circledR}$ Terminator v1.1 kit (AB Applied Biosystems) and sequence reactions were separated on a four capillary ABI PRISM ${ }^{\circledR} 3130$ Genetic Analyzer at IZSLER (Istituto Zooprofilattico Sperimentale della Lombardia e dell 'Emilia Romagna, Bianchi, 9 - 25124 Brescia, Italy). Sequences were assembled and edited using SeqMan module within Lasergene package, (DNAStar Inc., Madison, WI, USA) The obtained consensus sequences were subjected to BLAST search both at NCBI (http://www.ncbi.nlm.nih. gov/pubmed) and at 16S bacterial cultures Blast Server for the identification of prokaryotes (http://bioinfo. unice.fr/blast/).

\section{Results \\ Isolation, cultural characteristics and enumeration of Vibrio spp.}

The results from culture, enumeration and molecular identification of suspected Vibrio spp. in processed samples are shown in Table 1. Out of the 93 cultured samples, only $48(51.6 \%)$ yielded colonies on TCBS with culture characteristics suggestive of Vibrio spp. (Fig. 1; Fig. 2a and 2b). More than half (27) of processed seafood samples (46) yielded colonies on TCBS, while only 21 out of $47(44.6 \%)$ cultures of meat and meat products samples resulted in colonies on TCBS. No bacterial growth was revealed from the cultured samples of amberjack, shark, dusky grouper and sea needle, in addition to those from mutton, beef kebab and beef sausage (Table 1).

The highest bacterial count was recorded in a clam with a count of $3.8 \times 10^{4} \mathrm{CFU} \backslash \mathrm{g}$ from the seafood samples. The highest bacterial count in meat products was from chicken burger samples with $6.5 \times 10^{4} \mathrm{CFU} \backslash \mathrm{g}$ (Table 1 and Fig. 3). 


\section{Identification of Vibrio spp. by amplification and} sequencing of $16 S \mathrm{rDNA}$

All suspected isolates on TCBS were further analyzed molecularly by extraction of their DNA followed by sequencing of a portion of their $16 \mathrm{~S}$ rDNA. Sequence

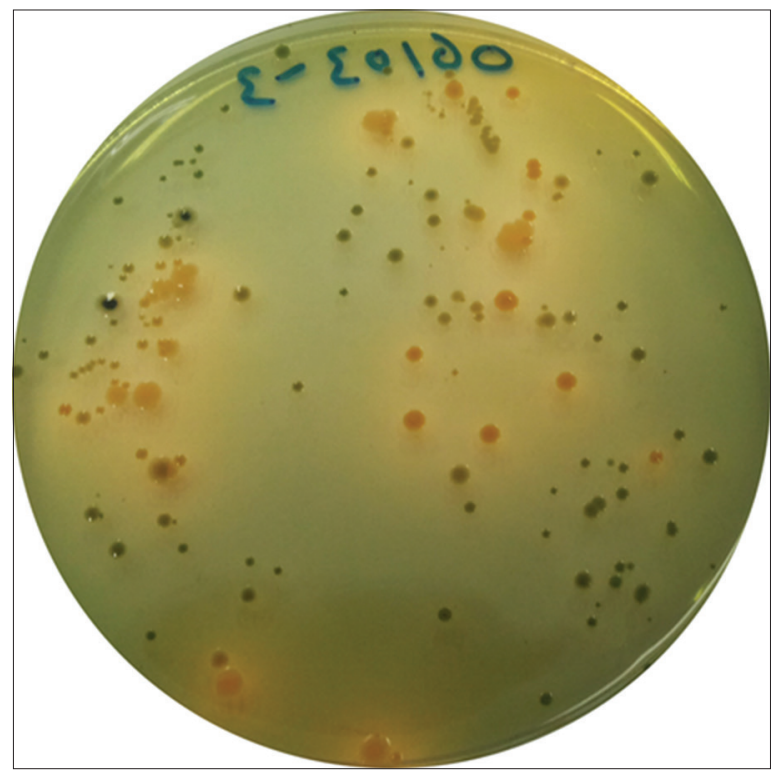

Fig. 1. TCBS plate showing the characteristic Vibrio spp. colonies (Green and yellow) during enumeration procedures.

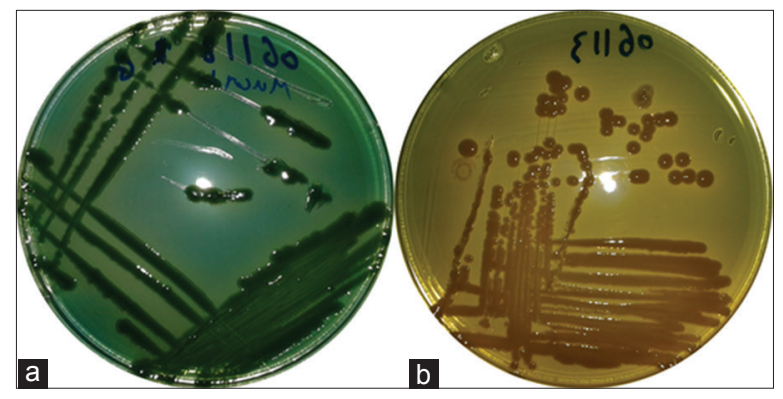

Fig. 2. Showing the pure consistent colonies of Vibrio parahemolyticus (a) and Vibrio alginolyticus colonies (b).

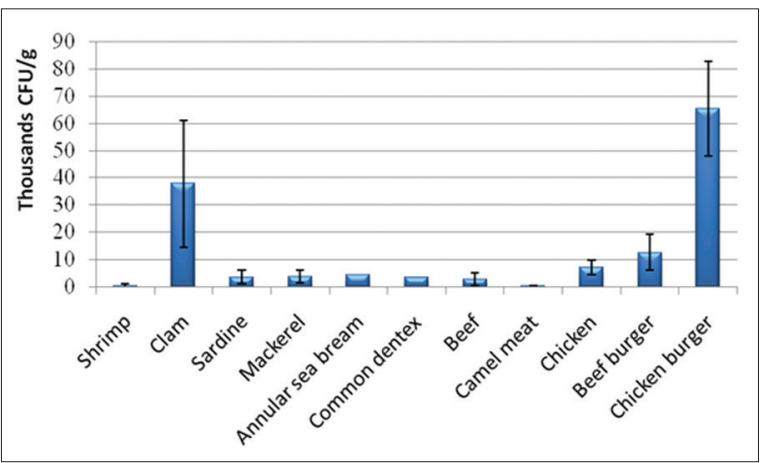

Fig. 3. Mean counts of Vibrio spp. in seafood, meat, and meat products samples. Error bar represents SD. analysis showed that only $11(22.9 \%)$ of these isolates were Vibrio spp. (Fig. 4 and Table 2).

Four out of the 11 Vibrio isolates were found to be Photobacterium damselae subsp. Damselae using the PCR-16S rDNA technique with $99 \%$ nucleotide identity (Table 2). Moreover, the molecular test has revealed the presence of Vibrio parahemolyticus in a camel meat sample, which is the first report of the isolation of Vibrio from camel meat.

\section{Discussion}

Our results represent the first report of isolation and identification of Vibrio spp. by sequencing of $16 \mathrm{~S}$ rDNA from seafood, meat and meat products samples in Libya. Only 11 samples out of 48 suspected Vibrio isolates $(22.9 \%)$ in this study were identified to be Vibrio spp. by $16 \mathrm{~S}$ rDNA sequencing. V. parahemolyticus and $V$. alginolyticus were the most frequently detected making up $27 \%$ of the isolates and the least frequently species was $V$. owensii $9 \%$. A previous study, which examined the occurrence of Vibrio in mussels harvested from Adriatic Sea, found $48.4 \%$ of samples were positive for Vibrio spp., among which $V$. alginolyticus was most frequently found $(32.2 \%)$ while $V$. parahaemolyticus was the least frequent (1.6\%) (Ripabelli et al., 1999). Another study determined the incidence of food borne pathogens in some European fish (France, Britain, Greece and Portugal) found $V$. parahaemolyticus was recorded in $35 \%$ of samples from Portugal and $14 \%$ from Greece but not in those from Britain or France (Davies et al., 2001).

Using conventional cultivation on TCBS, Jakšić et al. (2002) determined the occurrence of Vibrio spp. in fish and shrimps harvested from Adriatic Sea. They were able to isolate Vibrio spp. from $19.65 \%$ of samples. The most frequently found were V. parahemolyticus (9.4\%), V. vulnificus (6.8\%) and V. alginolyticus (3.4\%). Das et al. (2009) examined the occurrence of Vibrio parahaemolyticus in samples of finfish and Penaeus monodon from wholesale fish markets in Kolkata, India, by standard culture technique. The bacterium was isolated from $45.8 \%$ of shellfish and $16.7 \%$ of finfish samples. Xu et al. (2014) have investigated

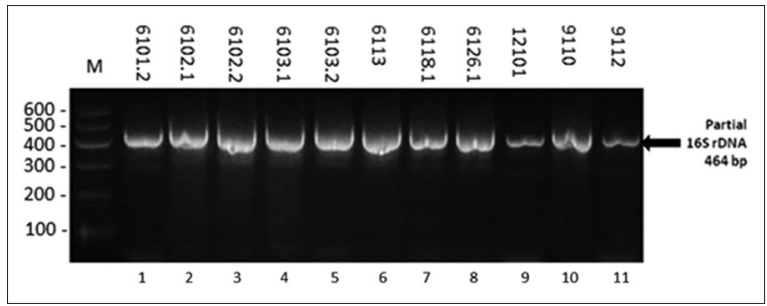

Fig. 4. Amplification of partial 16S rDNA (464 bp) of isolated Vibrio strains using the universal oligonucleotides primers (FOR S-D-Bact-0341-b-S-17 and REV S-D-Bact-0785a-A-21). Lane (M) contains the 6 fragments (100-600 bp) DNA marker. Lanes 1-11 contains isolated Vibrio spp. 
Table 2. Identification of suspected Vibrio spp. by PCR and sequencing of 16S rDNA.

\begin{tabular}{|c|c|c|c|c|}
\hline Blast NCBI search results & $\begin{array}{l}\text { Nucleotide } \\
\text { identity } \%\end{array}$ & $\begin{array}{l}\text { Isolates } \\
\text { code }\end{array}$ & Type of sample & $\begin{array}{l}\text { Sampling } \\
\text { area }\end{array}$ \\
\hline Vibrio owensii & 99 & 6101.2 & Chub mackerel (Scomber japonicas) & Tripoli \\
\hline Vibrio harveyi/Vibrio alginolyticus & 99 & 6102.2 & Chub mackerel (Scomber japonicas) & Tripoli \\
\hline Vibrio harveyi/Vibrio alginolyticus & 99 & 6113 & Clam shellfish & Tripoli \\
\hline Vibrio harveyi/Vibrio alginolyticus & 99 & 12101 & Shrimp & Tripoli \\
\hline Vibrio parahaemolyticus & 99 & 6118.1 & Camel meat & Regdalin \\
\hline Vibrio parahaemolyticus & 99 & 9110 & Common dentex & Tobruk \\
\hline Vibrio parahaemolyticus & 99 & 9112 & Annular sea bream & Tobruk \\
\hline $\begin{array}{l}\text { Photobacterium damselae subsp. } \\
\text { Damselae; } 99 \% \text { Vibrio }\end{array}$ & 99 & 6102.1 & Chub mackerel (Scomber japonicas) & Tripoli \\
\hline $\begin{array}{l}\text { Photobacterium damselae subsp. } \\
\text { Damselae; } 99 \% \text { Vibrio sp. }\end{array}$ & 99 & 6103.1 & Sardine & Tripoli \\
\hline $\begin{array}{l}\text { Photobacterium damselae subsp. } \\
\text { Damselae; } 99 \% \text { Vibrio sp. }\end{array}$ & 99 & 6103.2 & Sardine & Tripoli \\
\hline $\begin{array}{l}\text { Photobacterium damselae subsp. } \\
\text { damselae; Vibrio olivaceus }\end{array}$ & 99 & 6126.1 & Sardine & Tripoli \\
\hline
\end{tabular}

the prevalence, pathogenicity, and serotypes of $V$. parahaemolyticus in shrimp from Chinese retail markets. $V$. parahaemolyticus was detected in $(37.7 \%)$ of samples by the most probable number method.

$V$. owensii, which has been isolated from cultured crustaceous in Australia and recognized as a novel Vibrio spp. (Cano-Gómez et al., 2010) was among the suspected isolates in our study from samples of mackerel, a case which have not been reported earlier. From the results obtained in the present study, Photobacterium damselae subsp. damselae (formerly $V$. damsela) was the most frequently bacterium isolated (36\%) from the processed samples. This microorganism has been recognized as a pathogen for a wide variety of aquatic animals, such as crustaceans, molluscs, fish and cetaceans. In addition, this bacterial pathogen has been reported to cause diseases in humans and, for this reason, it may be considered as an agent of zoonoses (Austin, 2010). According to Bergey's Manual of Systematic Bacteriology (Thyssen and Oliver, 2005), $P$. damselae subsp. damselae belongs to the genus Photobacterium included in the family Vibrionaceae, displaying morphological characteristics typical of members of the family.

Occurrence of Vibrio spp. in meat and meat products is not widely reported. However, Zakhariev et al. (1976) has investigated $V$. parahemolyticus in pork sausage. Gardner (1980) have associated $V$. costicola with the spoilage of cured meats. Garcia-Lopez et al. (1998) had indicated the association of Vibrio spp. among other Gram-negative bacteria associated with spoilage of meat and meat products. Similarly, Doulgeraki et al. (2012) had concluded that $V$. parahemolyticus are among those organisms which are responsible for spoilage of raw meat during storage at different conditions. An interesting finding in this study was the isolation of $V$. parahemolyticus from camel meat, which has never been reported previously. On the other hand, none of the bacteria isolated from all the processed samples (beef, chicken, mutton, beef burger, chicken burger, beef kebab and beef sausage) belonged to Vibrio spp. Further, the mixed selling of chicken meats, beef and camel meat together with seafood products at the retail markets could have allowed the cross contamination from contaminated seafood/water directly to meat (Herrera et al., 2006; Nyachuba, 2010). The irresponsible and unhygienic act of washing chicken, beef and camel meats with sewage contaminated water/seawater could explain the reported Vibrio incidences (especially $V$. cholera and $V$. parahemolyticus) among these types of fresh meats (Maheshwari et al., 2011). This may also explain the isolation of $V$. parahemolyticus from camel meat in this study.

No Vibrio detection from mutton meat samples. This may be related to the low $\mathrm{pH}$ (acidic), associated with high conjugated linolenic and free fatty acids intermingling the mutton meat. This assumption ideally coincides with the relative bacterial inhibitory effect of sheep meat (mutton) fat reported by several studies (Reineccius, 1979; Sofos, 1994; Garcia-Lopez et al., 1998). However, lack of detection of Vibrio spp. in beef kebab and beef sausage samples may be attributed to the excessive dressing in spice, lemon/vinegar, garlic and onions that possess inhibitory effects on Vibrio growth (Beuchat, 1976).

In Libya, there is a lack of data concerning actual causes of food borne infections in general. So it is difficult to 
find a link between Vibrio spp. isolations and any of the reported food poisoning outbreaks in the country. However, correlations between $V$. parahemolyticus and food borne infections have been described in Taiwan (Pan et al., 1997), USA (Fyfe et al., 1997), France (Geneste et al., 2000), Mexico (Velazquez-Roman et al., 2012) and China (Ma et al., 2014).

One of the major risks involves the consumption of raw or undercooked seafood, meat and meat products that may be contaminated by food borne pathogens present in the marine/retail markets (Genigeorgis, 1985; Jay et al., 2005). Such risks are further increased if the food is mishandled during handling, slaughter, transportation, and processing where pathogens could multiply exponentially under favorable conditions (Oliver and Kaper, 1997).

In contrast to most other food borne pathogens, Vibrio spp. utilize aquatic habitats as their natural niche (Oliver and Kaper, 1997; Reidl and Klose, 2002). As a result, Vibrio spp. are commonly associated with polluted water, seafood, and other aquatic animals as the main source of contamination (Sutherland and Varnam, 2002). Food borne infections with Vibrio spp. are common in coastal cities where retail markets are close to the sea basin (Rebaudet et al., 2013). The close vicinity of seafood, meat and meat products retail markets as well as processing facilities to the sea basin amplifies the potentials of Vibrio spp. contamination to such foods (Jackson et al., 1997; Feldhusen, 2000; Sofos, 2008).

Finally, it is empirical to mention that the identity of the retrieved Vibrio parahemolyticus and $V$. harveyi were presumptively identified using morphological characteristics extracted from morphological cultural characteristics on the selective TCBS agar media. All isolates matched the standard morphological criteria previously established (Alsina and Blanch, 1994; Perilla et al., 2003; Austin and Austin, 2012). Molecular confirmation of the retrieved Vibrio isolates was done using partial amplification of $16 \mathrm{~S}$ rDNA using the universal oligo-nucleotides primers (FOR S-D-Bact0341-b-S-17 and REV S-D-Bact-0785-a-A-21) where the specific 464 bp amplicon has been documented coinciding with that reported by (Herlemann et al., 2011) for the same Vibrio spp. using the same specific primers and 16S rDNA PCR protocol.

\section{Acknowledgements}

This study was part of a project titled "Genetic authentication of bacterial isolates from meat and milk products in Libya and establishing the Food-borne Libyan-type Bacterial Collection (FLBC)" that was supported by a grant provided by the Libyan Authority for Research, Science and Technology (LARST). Authors are grateful to Veronica Papini, a technician in Istituto Zooprofilattico Sperimentale della Lombardia e dell'Emilia Romagna, Brescia, Italy, who performed the sequecing of the Partial 16S rDNA.

\section{References}

Alsina, M. and Blanch, A.R. 1994. A set of keys for biochemical identification of environmental Vibrio species. J. Appl. Bacteriol. 76, 79-85.

Austin, B. 2010. Vibrios as causal agents of zoonoses. Vet. Microbiol. 140, 310-317.

Austin, B. and Austin, D.A. 2012. Vibrionaceae representatives. In Bacterial fish pathogens (Springer), The Netherlands, pp: 357-411.

Beuchat, L. 1976. Sensitivity of Vibrio parahaemolyticus to spices and organic acids. J. Food Sci. 41, 899-902.

Cano-Gómez, A., Goulden, E.F., Owens, L. and Høj, L. 2010. Vibrio owensii sp. nov., isolated from cultured crustaceans in Australia. FEMS Microbiol. Lett. 302, 175-181.

Das, B., Manna, S., Sarkar, P. and Batabyal, K. 2009. Occurrence of Vibrio parahaemolyticus in different finfish and shellfish species. J. Food Saf. 29, 118-125.

Davies, A.R., Capell, C., Jehanno, D., Nychas, G.J. and Kirby, R.M. 2001. Incidence of foodborne pathogens on European fish. Food Control 12, 67-71.

Doulgeraki, A.I., Ercolini, D., Villani, F. and Nychas, G.J. 2012. Spoilage microbiota associated to the storage of raw meat in different conditions. Int. J. Food Microbiol. 157, 130-141.

Downes, F.P. and Ito, K. 2001. In Compendium of Methods for the Microbiological Examination of Foods. $4^{\text {th }}$ Ed. American Public Health Association, Washington DC, pp: 473-481.

Feldhusen, F. 2000. The role of seafood in bacterialfoodborne diseases. Microbes Infect. 2, 1651-1660.

Fyfe, M., Yeung, S., Daly, P., Schallie, K., Kelly, M. and Buchanan, S. 1997. Outbreak of Vibrio parahaemolyticus related to raw oysters in British Columbia. Can. Commun. Dis. Rep. 23, 145-148.

Garcia-Lopez, M., Prieto, M. and Otero, A. 1998. The physiological attributes of Gram-negative bacteria associated with spoilage of meat and meat products. Microbiol. Meat Poult. 1-34.

Gardner, G.A. 1980. Identification and ecology of saltrequiring Vibrio associated with cured meats. Meat sci. 5(1), 71-81.

Geneste, C., Dab, W., Cabanes, P., Vaillant, V., Quilici, M. and Fournier, J. 2000. Les vibrioses non cholériques en France: cas identifiés de 1995 à 1998 par le Centre National de Référence. Bull. Epidemiologie Hebdomadaire 9, 38-40.

Genigeorgis, C.A. 1985. Microbial and safety implications of the use of modified atmospheres to extend the storage life of fresh meat and fish. Int. J. Food Microbiol. 1, 237-251.

Harwood, V.J., Gandhi, J.P. and Wright, A.C. 2004. 
Methods for isolation and confirmation of Vibrio vulnificus from oysters and environmental sources: a review. J. Microbiol. Methods 59(3), 301-316.

Herlemann, D.P., Labrenz, M., Jürgens, K., Bertilsson, S., Waniek, J.J. and Andersson, A.F. 2011. Transitions in bacterial communities along the $2000 \mathrm{~km}$ salinity gradient of the Baltic Sea. ISME J. 5, 1571-1579.

Herrera, F., Santos, J., Otero, A. and García-López, M.L. 2006. Occurrence of foodborne pathogenic bacteria in retail prepackaged portions of marine fish in Spain. J. Appl. Microbiol. 100, 527-536.

Iwamoto, M., Ayers, T., Mahon, B.E. and Swerdlow, D.L. 2010. Epidemiology of seafoodassociated infections in the United States. Clin. Microbiol. Rev. 23, 399-411.

Jackson, T.C., Acuff, G. and Dickson, J. 1997. Meat, poultry, and seafood. Food microbiology fundamentals and frontiers ASM Press, Washington, DC, pp: 83-100.

Jakšić, S., Uhitil, S., Petrak, T., Bažulić, D. and Gumhalter Karolyi, L. 2002. Occurrence of Vibrio spp. in sea fish, shrimps and bivalve molluscs harvested from Adriatic sea. Food Control 13, 491-493.

Jay, J.M., Loessner, M.J. and Golden, D.A. 2005. Modern food microbiology. $7^{\text {th }}$ ed. Springer Science + Business Media. New York.

Kaysner, C.A. and DePaola, A. 2001. Vibrio. In Compendium of Methods for The Microbiological Examination of Foods. F.P. Downes and K. Ito, eds. Washington, DC, American Public Health Association, pp: 405-420.

Ma, C., Deng, X., Ke, C., He, D., Liang, Z., Li, W., Ke, B., Li, B., Zhang, Y., Ng, L. and Cui, Z. 2014. Epidemiology and etiology characteristics of foodborne outbreaks caused by Vibrio parahaemolyticus during 2008-2010 in Guangdong Province, China. Foodborne Pathog. Dis. 11, 21-29.

Maheshwari, M., Krishnaiah, N. and Ramana, D. 2011. Evaluation of Polymerase Chain Reaction for the detection of Vibrio cholerae in Contaminants. Ann. Biol. Res. 2, 212-217.

Newell, D.G., Koopmans, M., Verhoef, L., Duizer, E., Aidara-Kane, A., Sprong, H., Opsteegh, M., Langelaar, M., Threfall, J., Scheutz, F., van der Giessen, J. and Kruse, H. 2010. Food-borne diseases - the challenges of 20 years ago still persist while new ones continue to emerge. Int. J. Food Microbiol. 139 Suppl. 1:S3-15.

Nyachuba, D.G. 2010. Foodborne illness: is it on the rise? Nutr. Rev. 68, 257-269.

Oliver, J.D. and Kaper, J.B. 1997. Vibrio species. In: Doyle, M.P., Beuchat, L.R. and Montville, T.J. (eds) Food Microbiology. Fundamentals and Frontiers.
ASM Press, Washington DC, USA, pp: 228-264.

Pan, T.-M., Wang, T.-K., Lee, C.-L., Chien, S.-W. and Horng, C.-B. 1997. Food-borne disease outbreaks due to bacteria in Taiwan, 1986 to 1995 . J. Clin. Microbiol. 35, 1260-1262.

Perilla, M., Ajello, G., Bopp, C., Elliott, J. and Facklam, R. 2003. Manual for the laboratory identification and antimicrobial susceptibility testing of bacterial pathogens of public health importance in the developing world. Haemophilus influenzae Neisseria meningitidis Streptococcus pneumoniae Neisseria gonorrhoeae Salmonella serotype Typhi Shigella and Vibrio cholerae. WHO: Geneva, Switzerland.

Rebaudet, S., Sudre, B., Faucher, B. and Piarroux, R. 2013. Cholera in coastal Africa: a systematic review of its heterogeneous environmental determinants. J. Infect. Dis. 208 Suppl. 1:S98-106.

Reidl, J. and Klose, K.E. 2002. Vibrio cholerae and cholera out of the water and into the host. FEMS Microbiol. Rev. 26, 125-139.

Reineccius, G. 1979. Symposium on meat flavor offflavors in meat and fish-A review. J. Food Sci. 44, 12-24.

Ripabelli, G., Sammarco, M.L., Grasso, G.M., Fanelli, I., Caprioli, A. and Luzzi, I. 1999. Occurrence of Vibrio and other pathogenic bacteria in Mytilus galloprovincialis (mussels) harvested from Adriatic Sea, Italy. Int. J. Food Microbiol. 49, 43-48.

Sofos, J.N. 1994. Microbial growth and its control in meat, poultry and fish. In: Quality Attributes and Their Measurement in Meat, Poultry, and Fish Products. A.M. Pearson and T.R. Dutson (Eds.). Blackie Academic and Professional, Glasgow, U.K, pp: 359-403.

Sofos, J.N. 2008. Challenges to meat safety in the $21^{\text {st }}$ century. Meat Sci. 78, 3-13.

Sutherland, J. and Varnam, A. 2002. de, W., Blackburn, C., McClure, P.J., editors. Enterotoxinproducing Staphylococcus, Shigella, Yersinia, Vibrio, Aeromonas and Plesiomonas. Foodborne pathogens hazards, risk analysis and control. Cambridge: Woodhead Publishing, pp: 385-415.

Thyssen, A. and Oliver, F. 2005. "Genus II. Photobacterium". Bergey's manual of systematic bacteriology, $2^{\text {nd }}$ ed., Vol. 2, The Proteobacteria, Part B, The Gammaproteobacteria, Brenner, D.J., Krieg, N.R., Staley, J.T., Garrity, G.M., eds. New York, USA, Springer, pp 546-552.

Velazquez-Roman, J., León-Sicairos, N., FloresVillaseñor, H., Villafaña-Rauda, S. and CanizalezRoman, A. 2012. Association of pandemic Vibrio parahaemolyticus O3: K6 present in the coastal environment of Northwest Mexico with cases of recurrent diarrhea between 2004 and 2010. Appl. 
Environ. Microbiol. 78, 1794-1803.

Xu, X., Wu, Q., Zhang, J., Cheng, J., Zhang, S. and Wu, K. 2014. Prevalence, pathogenicity, and serotypes of Vibrio parahaemolyticus in shrimp from Chinese retail markets. Food Control 46, 81-85.
Zakhariev, Z., Tyufekchiev, T., Valkov, V. and Todeva, M. 1976. Food poisoning caused by parahaemolytic and NAG vibrios after eating meat products. J. Hyg. Epidemiol. Microbiol. Immunol. 20, 150-156. 